Research Article

\title{
Evaluation of availability and utilization of obstetric care services and entitlements under Janani Suraksha Yojana in Mysore, India
}

\author{
Hugara Siddalingappaa ${ }^{1}$, Narayana Murthy M. R. ${ }^{2}$, Maya Mascarenhas ${ }^{3}$, $\operatorname{Varsha~Hoogar}^{2}$, \\ Pradeep T. S. ${ }^{2}$, Sulekha T. ${ }^{4}$, Prem K. Mony ${ }^{4}$
}

\author{
${ }^{1}$ Department of Community Medicine, Mandya Institute of Medical Sciences, Mandya, Karnataka 570015, India \\ ${ }^{2}$ Department of Community Medicine, JSS Medical College, Mysore, Karnataka, India \\ ${ }^{3}$ MYRADA, Bengaluru, Karnataka, India \\ ${ }^{4}$ Department of Community Health and Epidemiology, St. John's Medical College, Bengaluru, Karnataka, India
}

Received: 06 July 2016

Accepted: 04 August 2016

\section{*Correspondence:}

Dr. Hugara Siddalingappaa,

E-mail: siddalingsh@yahoo.co.in

Copyright: () the author(s), publisher and licensee Medip Academy. This is an open-access article distributed under the terms of the Creative Commons Attribution Non-Commercial License, which permits unrestricted non-commercial use, distribution, and reproduction in any medium, provided the original work is properly cited.

\begin{abstract}
Background: To reduce maternal and infant deaths due to preventable causes by promoting institutional delivery, conditional cash transfer scheme, Janani Suraksha Yojana (JSY) program was launched in India. The aim of the study was to assess the availability and utilization of obstetric care services and monetary benefits under the scheme by pregnant women, completeness of services and timeliness of sanction of cash incentives and its effect on institutional deliveries in the study area. Design of the study was community based cross- sectional survey.

Methods: Mixed method research done in four Primary Health Centre (PHC)s selected by stratified random sampling method using survey and Focussed Group Discussion methods. Statistical analysis was univariate and bivariate analysis using SPSS.

Results: Among 510 mothers interviewed, registration of pregnancies was $100 \%$ and $99.6 \%$ mothers had more than three ANC check ups. Institutional delivery rate was $98.8 \%$. Among the 484 scheme eligible, 385 (79.5\%) had got JSY money. Reason for not getting the money were, lack of documents, bank accounts, not linking UID (Aadhar) number to the bank account and delay was due to shortage of funds in the PHC.

Conclusions: CPSMS was the major method of disbursement (65\%). Most of the mothers got money after three to four months delay. $63 \%$ of the study participants in the study area had got full range of obstetric care services recommended through JSY.
\end{abstract}

Keywords: Janani Suraksha Yojana, Evaluation, Community based, Mysore

\section{INTRODUCTION}

Ongoing social and health reforms in India are improving national health indicators slowly. Infant mortality rate (IMR) has been brought down to 40 per 1000 live births, and MMR 178 per 100000 live births. ${ }^{1,2}$ Still there is lot of scope for improvement as many children and mothers die from preventable causes.
On an average, an Indian family spends Rs.4502 in urban areas and Rs.2224 in rural areas for childbirth. ${ }^{3} \mathrm{~S}$ Mukharji observed that after adjusting for out-of-pocket maternal health care expenditure, the poverty increased by $20 \%$ in urban and $19 \%$ in rural areas. ${ }^{3}$

Janani Suraksha Yojana (JSY) scheme is launched under National Rural Health Mission (NRHM) to reduce infant 
and maternal mortality by promoting institutional obstetric care utilization through conditional cash transfer. It entrusts ASHA (Accredited social health activist) with responsibilities to identify pregnant women and help her till immunization of her child. ${ }^{4}$

Under this scheme in the study area, below poverty line families and couples of scheduled caste and tribe are eligible for monetary benefit of Rs. 700 for normal delivery and LSCS at government hospitals and Rs. 1500 for LSCS at recognized private hospitals. ${ }^{5}$ The monetary benefit is to take care of the expenses towards transportation, admission, hospital stay and immediate postnatal care. Ideally this amount is to be sanctioned within two days of delivery. ${ }^{6}$ This study was done to evaluate this program for its availability and utilization in Mysore.

\section{Objectives}

- To assess the availability of obstetric care services and monetary benefits to pregnant women eligible for $J S Y$ scheme.

- To assess the utilization of Obstetric care services and monetary benefits provided to the pregnant women under JSY scheme.

\section{METHODS}

Study design and setting: Cross sectional mixed method community based health service research done in Four PHC areas of Mysore during July to October 2014.

Selection of study villages: Multistage stratified random sampling method was used to cover 128 PHCs of Mysore District. First stage stratification of PHCs in study area was done based on percentage of mothers disbursed with JSY money in previous year, as representation was desired from PHCs with varying performance in JSY implementation. PHCs thus categorized into high, average and low performing, were again classified based on their $\mathrm{MCH}$ indicators as shown in Table 1, and cumulative score was used to select three PHCs from 95 non tribal PHCs representing high (Udbhuru), average (Hedthale) and low (Madapura) performing PHCs. One PHC with highest tribal population among 33 tribal PHCs was selected (B Matkere).

\section{Table 1: Scoring system for stratification of PHCS} and for their selection.

\begin{tabular}{|llll|}
\hline $\begin{array}{l}\text { Criteria (values for the year } \\
\text { 2013-14) }\end{array}$ & $\mathbf{1}$ & 2 & 3 \\
\hline ANC registration (\%) & $<75$ & 75 to 90 & $>90$ \\
\hline Early ANC registration (\%) & $<75$ & 75 to 90 & $>90$ \\
\hline Low birth weight (LBW) rate (\%) & $>5$ & 05 to 2 & $<2$ \\
\hline $\begin{array}{l}\text { Infant mortality rate (per 1000 live } \\
\text { births) }\end{array}$ & $>30$ & 30 to 10 & $<10$ \\
\hline $\begin{array}{l}\text { Percentage of mothers who got JSY } \\
\text { benefit }\end{array}$ & $<25$ & 25 to 50 & $>50$ \\
\hline
\end{tabular}

\section{Study participants}

Mothers who had delivered between January $1^{\text {st }}$ to December $31^{\text {st }}$ of 2013 and belonged to the study area were interviewed.

\section{Sample size}

All the mothers satisfying the inclusion criteria in the study area were included, which formed a sample size of 510 .

\section{Study instruments}

Semi-structured pretested questionnaire in local language was used after validation by translation and backtranslation method. Discussion key was used during FGDs.

\section{Data collection}

During the house to house survey by trained Medico Social Workers using questionnaire, mothers were interviewed and $\mathrm{MCH}$ tracking (Thayi) card and other hospital records were referred wherever available to get details regarding sociodemographic details, obstetric care and bank passbook or JSY acknowledgement for monetary benefit details.

Further details regarding $\mathrm{MCH}$ care, challenges for scheme implementation were collected using focused group discussions (FGD) with ASHA workers in the PHC area.

\section{Study definitions}

'Availability'- 'provision of a hospital with qualified doctor to provide obstetric services within a distance of $25 \mathrm{~km}$ from the mother's village and ANM or ASHA worker to help mothers in getting the obstetric care, implementation of JSY monetary benefit scheme in the area'.

'Completeness'- was defined using a checklist of services to be provided to pregnant mothers and the baby. ${ }^{7}$

\section{Statistical analysis}

Data was entered into excel sheet and analysed using SPSS 22.1 software. Univariate analysis included proportion, mean and standard deviation, median range of the variables. Bivariate analysis was done using student $t$ test to find the difference in mean values. Focus group discussion (FGD) findings of four PHCs were summarised according to grounded theory.

\section{Ethical issues}

Ethical clearance for the study was obtained from Institutional ethical committee of JSS Medical College, 
Mysore. Informed written consent of each mother was obtained before staring the interview. FGD was conducted after taking informed verbal consent from the ASHA workers.

\section{RESULTS}

Three nontribal PHCs selected for the study covered 59319 people in 40 villages and tribal PHC had a population of 9395 in its seven villages and 25 hamlets. 510 mothers in the study area satisfied the inclusion criteria and all agreed to participate in the study.

Most of the study participants belonged to 18 to 25 years age group. Mean age at marriage and mean age at first pregnancy were $18.8 \pm 2.2$ and $20.1 \pm 2.5$ respectively. $11.4 \%$ and $16.3 \%$ mothers had married before the age of 18 years and conceived before 19 years respectively.
$90 \%$ of the mothers had a hospital with labour facility within $15 \mathrm{kms}$ distance; out of these hospitals $77 \%$ had LSCS facility. Villages in the study area had good vehicle connectivity other than 108 ambulances. Few tribal hamlets were not having connecting motorable road. All PHCs had implemented the JSY scheme. Among 510 mothers interviewed 484 were eligible for JSY monetary benefits. $332(68.5 \%)$ belonged to Scheduled caste or tribe and remaining $152(31.5 \%)$ were from below poverty line (BPL) families.

Registration of pregnancies was $100 \%$ in the study area, $97 \%$ had registered within 12 weeks of gestation and 99.6\% mothers had more than three ANC checkups. Institutional delivery rate was $98.8 \%$ with a greater proportion $(81.7 \%)$ delivering in Govt hospitals with the help of doctors $(96.4 \%)$. More than two thirds of these mothers utilized 108 (free government) ambulance services. ASHA had accompanied $96 \%$ of the mothers to hospital.

Table 2: Profile of PHCs selected for the JSY scheme evaluation.

\begin{tabular}{|c|c|c|c|c|c|}
\hline & $\begin{array}{l}\text { PHC Udbhuru } \\
\text { (High } \\
\text { performing) }\end{array}$ & $\begin{array}{l}\text { PHC Hedthale } \\
\text { (Average performing) }\end{array}$ & $\begin{array}{l}\text { PHC Madapura } \\
\text { (Low } \\
\text { performing) }\end{array}$ & $\begin{array}{l}\text { PHC B. } \\
\text { Matkere } \\
\text { (Tribal area) }\end{array}$ & Total \\
\hline Population & 14808 & 26525 & 17986 & 9395 & 68714 \\
\hline Number of villages & 03 & 22 & 15 & 32 (20 hamlets) & 72 \\
\hline $\begin{array}{l}\text { Distance from district } \\
\text { headquarters }\end{array}$ & 15 & 40 & 45 & 90 & - \\
\hline Medical officer & 01 & $\begin{array}{l}\text { In charge MO visits } \\
\text { twice weekly }\end{array}$ & 01 & 01 & 03 \\
\hline ANMs & 03 & 03 & 04 & 01 & 11 \\
\hline ASHAs & 10 & 22 & 15 & 08 & 55 \\
\hline $\begin{array}{l}\text { Number of live births } \\
\text { among participants }\end{array}$ & 141 & 205 & 100 & 64 & 510 \\
\hline
\end{tabular}

Table 3: Distribution of study participants according to of obstetric profile in study PHCs.

\begin{tabular}{|lllll|l|}
\hline Particulars & $\begin{array}{l}\text { PHC Udbhuru } \\
\text { (High } \\
\text { performing) }\end{array}$ & $\begin{array}{l}\text { PHC Hedthale } \\
\text { (Average } \\
\text { performing) }\end{array}$ & $\begin{array}{l}\text { PHC Madapura } \\
\text { (Low performing) }\end{array}$ & $\begin{array}{l}\text { PHC B. } \\
\text { Matkere } \\
\text { (Tribal area) }\end{array}$ & Total \\
\hline $\begin{array}{l}\text { Mean Age of the study } \\
\text { population }\end{array}$ & $23.4 \pm 2.8$ & $23.3 \pm 3.2$ & $22.8 \pm 2.6$ & $22.4 \pm 2.8$ & $23.1 \pm 2.9$ \\
\hline $\begin{array}{l}\text { Mean Age at marriage } \\
\text { (SD) }\end{array}$ & $18.8 \pm 2.3$ & $19.1 \pm 2.8$ & $18.6 \pm 1.3$ & $18.4 \pm 1.0$ & $18.8 \pm 2.2$ \\
\hline $\begin{array}{l}\text { \% of mothers married } \\
\text { before 18 years }\end{array}$ & 16.3 & 13.2 & 4.0 & 6.3 & 11.4 \\
\hline $\begin{array}{l}\text { Mean Age at first } \\
\text { pregnancy }\end{array}$ & $20.1 \pm 2.5$ & $20.5 \pm 3.0$ & $19.6 \pm 1.3$ & 12.5 & $20.1 \pm .5$ \\
\hline $\begin{array}{l}\% \text { of mothers with 1 } \\
\text { pregnancy before 19 yrs }\end{array}$ & 21.3 & 18.0 & 8.0 & $42(65.6)$ & 16.3 \\
\hline Primiparous women $(\%)$ & $59(41.8)$ & $99(48.3)$ & $47(47.0)$ & $247(48.5)$ \\
\hline
\end{tabular}


Among the eligible, 385 (79.5\%) had got the JSY benefits. Four mothers with more than two live births had got JSY money. Less than one percent of mothers got money at the hospital. Most got it after a median delay of 120 days (Q1, Q3 is 60, 180 days). Nearly two thirds were transferred through the recommended, online money transfer i.e. Centralized plan scheme monitoring system (CPSMS). The reason for not getting the money even though they were eligible, as told to the mothers were, not having the bank account (17.5\%), not submitting Universal Identification (Aadhar) number to bank or other documents to $\mathrm{PHC}(16.5 \%)$, shortage of funds in the PHC (46\%), death of the baby during infancy $(5 \%)$ and others $(15 \%)$.

Table 4: Distribution of study participants according to obstetric care service utilization in different PHCs.

\begin{tabular}{|c|c|c|c|c|c|}
\hline Particulars & $\begin{array}{l}\text { PHC Udbhuru } \\
\text { (High } \\
\text { performing) }\end{array}$ & $\begin{array}{l}\text { PHC Hedthale } \\
\text { (Average } \\
\text { performing) }\end{array}$ & $\begin{array}{l}\text { PHC Madapura } \\
\text { (Low } \\
\text { performing) }\end{array}$ & $\begin{array}{l}\text { PHC B. } \\
\text { Matkere } \\
\text { (Tribal area) }\end{array}$ & Total \\
\hline $\begin{array}{l}\text { Number of Institutional } \\
\text { deliveries }\end{array}$ & $137(97.2 \%)$ & $205(100 \%)$ & $100(100 \%)$ & $63(98.4 \%)$ & $505(98.8 \%)$ \\
\hline \multicolumn{6}{|c|}{ Type of facility where delivery was conducted $(\mathrm{N}=505)$} \\
\hline Government & $111(81.0 \%)$ & $189(92.1 \%)$ & $93(93 \%)$ & $20(31.7 \%)$ & $413(81.7 \%)$ \\
\hline Private & $26(19 \%)$ & $16(8.9 \%)$ & $7(7 \%)$ & $43(68.3 \%)$ & $92(18.3 \%)$ \\
\hline \multicolumn{6}{|c|}{ Mode of delivery(N=510) } \\
\hline Vaginal & $120(85.1 \%)$ & $169(82.4 \%)$ & $87(87 \%)$ & $56(87.5 \%)$ & $432(84.7 \%)$ \\
\hline LSCS & $21(14.9 \%)$ & $36(17.6 \%)$ & $13(13 \%)$ & $8(12.5 \%)$ & $78(13.3 \%)$ \\
\hline \multicolumn{6}{|c|}{ Mode of transport used for delivery $(\mathrm{N}=505)$} \\
\hline 108 ambulance & $116(84.6 \%)$ & $124(60.4 \%)$ & $73(73.0 \%)$ & $46(73.0 \%)$ & $359(71.0 \%)$ \\
\hline Other vehicles & $21(15.4 \%)$ & $81(39.6 \%)$ & $27(27 \%)$ & $17(27 \%)$ & $146(29 \%)$ \\
\hline \multicolumn{6}{|c|}{ Did ASHA accompany to delivery } \\
\hline Yes & $128(93.4 \%)$ & $203(99.0 \%)$ & $95(95 \%)$ & $59(93.6 \%)$ & $485(96.0 \%)$ \\
\hline No & $9(6.4 \%)$ & $2(1 \%)$ & $5(5 \%)$ & $4(6.4 \%)$ & $20(4 \%)$ \\
\hline \multicolumn{6}{|c|}{ Person conducting the delivery (at hospital) } \\
\hline Doctor & $128(92.7 \%)$ & $100(100 \%)$ & $199(97.0 \%)$ & $61(95.0 \%)$ & $487(96.4 \%)$ \\
\hline Nurse & $13(7.3 \%)$ & 0 & $6(3 \%)$ & $2(3.5 \%)$ & $18(3.2 \%)$ \\
\hline
\end{tabular}

Table 5: Distribution of study participants according to disbursement of JSY monetary benefit in the study area.

\begin{tabular}{|c|c|c|c|c|c|}
\hline Particulars & $\begin{array}{l}\text { PHC Udbhuru } \\
\text { (High } \\
\text { performing) }\end{array}$ & $\begin{array}{l}\text { PHC Hedthale } \\
\text { (Average } \\
\text { performing) }\end{array}$ & $\begin{array}{l}\text { PHC Madapura } \\
\text { (Low } \\
\text { performing) }\end{array}$ & $\begin{array}{l}\text { PHC B. } \\
\text { Matkere } \\
\text { (Tribal area) }\end{array}$ & Total \\
\hline $\begin{array}{l}\text { Number of mothers } \\
\text { eligible for JSY money } \\
\text { (upto } 2 \text { live births) }\end{array}$ & $127(90 \%)$ & $198(96.5 \%)$ & $96(96 \%)$ & $63(98.5 \%)$ & $484(94.9 \%)$ \\
\hline $\begin{array}{l}\text { Eligible mothers who } \\
\text { got JSY money }\end{array}$ & $106(83.5)$ & $145(73.2 \%)$ & $77(80.2 \%)$ & $57(90.5 \%)$ & $385(79.5 \%)$ \\
\hline \multicolumn{6}{|c|}{ Duration for getting the monetary benefit in days } \\
\hline Median (Range) & $120(1-365)$ & $90(36-305)$ & $150(60-155)$ & $150(60-335)$ & $120(1-365)$ \\
\hline \multicolumn{6}{|c|}{ Mode of payment received } \\
\hline CPSMS* & $57(52.8 \%)$ & $115(78.3 \%)$ & $(88.3 \%)$ & $12(21.1 \%)$ & $251(64.8 \%)$ \\
\hline Cheque & $51(47.2 \%)$ & $30(20.4 \%)$ & $9(11.7 \%)$ & $45(78.9 \%)$ & $135(34.7 \%)$ \\
\hline Cash & 0 & $2(1.4 \%)$ & 0 & 0 & $2(0.5 \%)$ \\
\hline
\end{tabular}

* Centralized plan scheme monitoring system

$63 \%$ of the study participants and $66.5 \%$ of the mothers who were eligible for JSY had got complete services as per recommendation. There was higher incidence of prematurity $(\mathrm{P}=0.14)$, low birth weight $(\mathrm{P}=0.057)$ and mortality $(\mathrm{P}=0.06)$ among the incompletely served group, though it was not statistically significant.

FGDs reported that intranatal care was good in most of the utilized hospitals. Utilization of Govt hospital was 
maximum for delivery in all the PHCs except tribal PHC, where NGO run hospital was preferred more. There were few complaints regarding harsh behaviour of group D workers and nursing staff in the district hospital. Registration at district hospital took upto 30 mins, during which mother had to wait outside the labour room. ASHAs accompanying mothers were not allowed into district hospital labour complex which made the initial experience more frightening for mothers. Incidences of money being demanded from mothers by nurses in district and Talluka hospitals were reported. Doctors expected money for LSCS in few Talluka hospitals. ASHAs incentive for her participation in the scheme was sanctioned regularly in their monthly meetings. Inadequacy of basic facilities for their accommodation at the hospital discouraged them from staying in the hospital till mother's discharge. ASHAs opined that though the awareness about JSY and its utilization are high, the money sanctioned is not being used for the maternal care. In many families husband draws the money and utilizes for his needs (alcohol in case of tribal area).

\section{DISCUSSION}

Obstetric care services provided to the mothers in the study area had high coverage. In the present study mother's literacy rate was nearly $80 \%$ which could be one of the reasons for high coverage. Child marriage practices were confirmed during the FGDs. In tribal mothers most were child marriages as they follow their own social norm.

Present study observed complete and early registration of pregnancy, which is result of efforts of ASHAs, who track newly married women for pregnancy. As reported during FGDs, people in this region hesitate to reveal about pregnancy till three months as they believe in "evil eye" effect leading to miscarriages. Early registration shows people's confidence in ASHAs.

In tribal areas of Mysore only $66 \%$ of the mothers was living in vehicle accessible hamlets during 2010-12 as found by SVYM study. ${ }^{8}$ In the present study $71 \%$ of the mothers had utilized 108 ambulances which could be called over phone. As ASHAs recollected during the FGD, during a strike of 108 ambulance drivers, these taxi drivers cancelled other trips and attended to the calls of ASHAs.

96\% of the mothers were accompanied by ASHAs to the delivery and most had stayed in the hospital till mother was shifted to the ward. Mukhyopadhyay and Deoki Nandan had observed non availability of ASHAs and other paramedical staff as a reason for decreased awareness and utilization of the JSY. ${ }^{7,9}$

Higher numbers of deliveries were conducted by doctors in the study area as more than $60 \%$ of the deliveries among study subjects happened in Cheluvamba hospital which is attached to Mysore Medical College having Post
Graduates posted in labor room 24x7. Other taluka hospitals and CHCs had gynaecologists. NGO hospital in tribal area had a gynaecologist and trained BAMS doctors round the clock.

Among the 484 eligible, 385 mothers had got JSY money. According to Modugu and Lim, during 2006-07 national average for the utilization of JSY was $6 \%$ which ranged from $5 \%$ to $44 \%{ }^{10,11}$ In tribal areas of Mysore, during $2011-12$ only $69 \%$ of those submitted the necessary documents had got the benefit. ${ }^{8}$ This improved beneficiary rate could be due to change in socioeconomic background of the study areas and increasing awareness with the time.

Median delay in study area was 120 days. Health workers maintain a seniority list and money is disbursed accordingly when sanctioned to PHC. FGD revealed that repeated effort to transfer money through CPSMS had resulted in delay. ASHAs in all the areas felt, cheque was the ideal method and the delay has increased since the CPSMS method was implemented. The reason for this was probed with both the PHC staff and Bank officials. On enquiring the issue bank officials said software was very well developed but the problems occur when there is typographic disparity between the name in bank account and CPSMS data (sent from PHCs). The same was conveyed to the PHC staff and they acknowledged that they didn't know this and agreed that such differences were present.

Delay in money disbursement varied from seven days to six months in Jarkhand and Orissa. ${ }^{5,7}$ Major reasons for delay was lack of funds, delay in producing documents, lack of awareness in many parts of the country including the study area. ${ }^{7,8,10}$

The amount transferred was not meeting the expenses of frequent trips to PHC and Bank. ASHAs also said that people open account with minimum or nil balance. After the money is transferred, bank people ask them to leave minimum amount in account. This results in effective payment of 500 or less. The amount of JSY which is meant for the expenses of hospital delivery and transport was used for buying household requirements, cosmetics and clothes for her or baby, to repay the borrowings. Many times they dint get to know that money had been deposited in her account. Money sanctioned was used for food $(44 \%)$, travel $(33 \%)$, drugs $(58 \%)$ and others like depositing for children $(19 \%)^{7}$

PHC Medical officers interview and other evaluation methods showed that the main reason for delay was irregular release of funds to the PHCs which happens once in 3 to 4 months and lack of technical knowledge of clerical staff in handling computer software.

According to FGDs conducted in the area, institutional deliveries have increased significantly and helped in reducing the infant and maternal mortality. ASHAs and 
ANMs in Jharkhand felt improved MCH service and its utilization because of JSY during Concurrent evaluation in Jharkhand.

\section{CONCLUSION}

Obstetric care levels were above $95 \%$ among the mothers in all the PHCs. $79.5 \%$ of the eligible participants got the monetary benefit. CPSMS was the major method of disbursement $(65 \%)$. Most of the mothers got money after three to four months delay. $63 \%$ of the study participants in the study area had got full range of antenatal intranatal and postnatal services recommended through JSY.

Funding: This work was funded by Maternal Health Task Force at the Harvard T. H. Chan School of Public Health through Grant \#01065000621 from the Bill \& Melinda Gates Foundation. The Maternal Health Young Professionals (India) Mentoring Program was based at St John's Medical College \& Research Institute, Bangalore, Karnataka India,

Conflict of interest: None declared

Ethical approval: The study was approved by the Institutional Ethics Committee

\section{REFERENCES}

1. Sample Registration Bulletin - SRS Bulletin. 2014. Available from: http://censusindia.gov.in/vital_statistics/SRS_Bullet ins/SRS\%20Bulletin\%20-Sepetember\%202014.pdf

2. Mukherjee S, Singh A, Chandra R. Maternity or catastrophe: A study of household expenditure on maternal health care in India. Health. 2013;5(1):109-18.

3. RHS bulletin. Rural health statistics in India. 2012. Statistics division, Ministry of health and family welfare, Government of India.

4. Ministry of Health and Family Welfare (MoHFW); health division, Government of India. Janani Suraksha Yojana, features and frequently asked questions. 2006. Available from; http://mohfw.nic.in/WriteReadData/1892s/file2899526408.pdf
5. UNFPA. Concurrent assessment of Janani Suraksha yojana in selected states. 2014. Available from: http://countryoffice.unfpa.org/india/drive/JSYConcu rrentAssessment.pdf

6. Indian Clinical Epidemiological Network (India CLEN) \& Population Foundation of India (PFI). Concurrent Evaluation of the Reach, Effectiveness and Impact of the Mukhya Mantri Janani Shishu Swasthya Abhiyan. 2009-10.pdf Available from: http://inclentrust.org/inclen/uploadedbyfck/file/com plete $\% 20$ Project/Concurrent $\% 20$ Evaluation $\% 20$ of $\%$ 20the $\% 20$ Reach, $\% 20$ Effectiveness $\% 20$ and $\% 20$ Imp act $\% 20$ of $\% 20$ the $\% 20$ Mukhya\%20Mantri\%20Janani \%20Shishu\%20Swasthya\%20Abhiyan.pdf

7. Nandan D. National Institute of Health and Family welfare. An assessment of functioning and impact of janani suraksha yojana in Orissa 2007-08. Available from: I\%20Reports/Orissa/ORISSA.pdf

8. svym_-_brief_29-09-12_final_for_print.pdf Available from: http://www.chsj.org/uploads/1/0/2/1/10215849/svy m_-_brief_29-09-12_final_for_print.pdf

9. Mukhopadhyay D, Saren A, Biswas A, Panja T, Sinha N, Sinhababu A. Are institutional deliveries promoted by Janani Suraksha Yojana in a district of West Bengal, India? Indian J Public Health. 2012;56(1):69.

10. Modugu HR, Kumar M, Kumar A, Millett C. State and socio-demographic group variation in out-ofpocket expenditure, borrowings and Janani Suraksha Yojana (JSY) programme use for birth deliveries in India. BMC Public Health. 2012;12(1):1048.

11. Lim SS, Dandona L, Hoisington JA, James SL, Hogan MC, Gakidou E. Impact of conditional cash transfers in india. The Lancet. 2010;375(9730):2009-23.

Cite this article as: Siddalingappaa $\mathrm{H}$, Murthy NMR, Mascarenhasc M, Hoogar V, Pradeep TS, Sulekha T, Mony PK. Evaluation of availability and utilization of obstetric care services and entitlements under Janani Suraksha Yojana in Mysore. Int J Community Med Public Health 2016;3:2487-92. 